E3S Web of Conferences 1, 39007 (2013)

DOI: $10.1051 / \mathrm{e} 3$ sconf/20130139007

(C) Owned by the authors, published by EDP Sciences, 2013

\title{
Zinc (Zn) Analysis in Milk by Microwave Oven Digestion and Differential Pulse Anodic Stripping Voltametry (DPASV) Technique
}

\author{
$\underline{\text { Mohineesh }}^{1}$, A. Raina ${ }^{1}$, J. Raj ${ }^{1}$ and T. D. Dogra ${ }^{1}$ \\ ${ }^{1}$ Department of Forensic Medicine and Toxicology, All India Institute of Medical Sciences (AIIMS), New Delhi, India- \\ 110029, mohineesh123@rediffmail.com, +91-9891564641
}

\begin{abstract}
Milk is very important component of human diet. The presence of over limit of heavy metal in milk may create significant health problems. In the present study, the direct determination of Zinc (Zn) heavy metal in milk samples of different brands was carried out by differential pulse anodic stripping Voltammetric technique at Hanging Mercury Drop Electrode (HMDE). Milk samples were processed by microwave oven digestion using HP/VHP Vessels and TFM Liners and nitric acid $\left(\mathrm{HNO}_{3}\right)$. Determination of $\mathrm{Zn}$ was made in acetate buffer ( $\mathrm{pH} 4.6$ ) with a sweep rate (scan rate) of $59.5 \mathrm{mV} / \mathrm{s}$ and pulse amplitude $50 \mathrm{mV}$ by HME by standard addition method. The solution was stirred during pre-electrolysis at $-1150 \mathrm{mV}$ (vs. $\mathrm{Ag} / \mathrm{AgCl}$ ) for 90 seconds and the potential was scanned from $-1150 \mathrm{~V}$ to $+100 \mathrm{~V}$ (vs. $\mathrm{Ag} / \mathrm{AgCl}$ ). The zinc ions were deposited by reduction at $-1150 \mathrm{mV}$ on HMDE. The stripping current arising from the oxidation of metal was correlated with the concentration the metal in the sample. As a result the minimum level of $\mathrm{Zn}$ observed in the milk sample of different brands was determined as $2.28 \mathrm{mgL}^{-1}$.
\end{abstract}

Keywords: Anodic stripping Voltametry, Hanging mercury dropping electrode, Heavy metals, Zinc, milk.

\section{Introduction}

Milk is an important source of minerals including trace elements for suckling as well as for human nutrition. Knowing the content of trace elements in the milk as a function of their intake prevents either insufficient or excessive quantity of trace elements from being supplemented. The content of micro-elements in the milk can be an important indicator whether the animals are being saturated with these elements and a parameters of the milk`s biological quality as a nutrient. [Bonzene et al, 2005] Increase in industrial and agricultural processes have resulted in increased concentration of metals in the air, water and soil. These metals are taken in by plants and consequently accumulate in their tissues. Animals that graze on such contaminated plants and drink from polluted waters also accumulate such metals in their tissues and milk if lactating [Yahaya M.I et al 2010]. A large amount of these metals taken in by plants and animals subsequently find their way into the food chain. This ever increasing pollution has given rise to concern on the intake of harmful metals in humans. Metals enter the human body through inhalation, ingestion or absorption through the skin [Ogabiela et al, 2010 and Ahmed WMS 2002]. The intake through ingestion depends on food habit. Cow milk which is a very important food stuff consumed by man is one of the major sources [Farid et al, 2004]. In recent times, the amount of metals in cow milk is widely studied, particularly in industrialized and polluted areas of the developed and the developing countries of the world since animals grazed freely on open fields are considered as bio-indicators of environmental pollution [Korenekong et al, 2002 and Li Quang et al 2009].Differential pulse anodic stripping Voltammetry (DPASV) is a powerful and established method for the analysis of trace metals in milk samples available in Delhi Market, India. It is possible to analyze very low level of $\mathrm{Zn}$ using ASV. It can detect levels in the range of part-per-million (ppm) or even part-per-billion (ppb) (i.e., 10-10 M). Several other methods are also used routinely in addition to DPASV, such as Atomic Absorption Spectrometry (AAS) and Xray fluorescence spectrometry, Inductive coupled plasma, but advantages of using DAPSAV are that it is a successful, new, rapid, simple, selective and inexpensive for qualitative and quantitative determinations of heavy metals. ${ }^{[6]}$ The other reasons for using DPASAV technique are: It has extremely low detection limits, and it works in the presence high salt concentrations. It allows metal speciation and can differentiate between free and complexed metal ions. It can also analyze non-metals such as anions or organics. In this study, DPASV technique was used to determine Zinc metal in various milk samples of Delhi (India) using Hanging mercury 
dropping electrode (HMDE) as a working electrode. Consequently, the most appropriate conditions were fixed to determine Zinc amount as an analytical application of DPASV on a HMD electrode.

\section{Materials and Methods}

\section{Instrumentation / Accessories and Operating Conditions}

Voltammetric determination of $\mathrm{Zn}$ was performed with Trace Metal Analyzer (797 VA Computrace ,Metrohm AG Ltd, Switzerland) with three-electrode system consisting Hanging mercury drop electrode(HMDE) as working electrode, Platinum $(\mathrm{Pt})$ as auxiliary electrode and $\mathrm{Ag} / \mathrm{AgCl} / \mathrm{KCl}(3 \mathrm{~mol} / \mathrm{L})$ as reference electrode. The operating parameters are given in Table 1.

\section{Reagents/Chemicals}

Suprapure acetic acid (Merck Darmstadt, Germany), Nitric acid, Liquor ammonia, ammonium oxalate, and sulphuric acid (Qualigens Fine Chemicals, A Division of GlaxoSmithKline Pharmaceuticals Limited, Mumbai, India), Ultra pure-deionize water was obtained from Milli-Q ( Biocel System, Millipore)

\section{Preparation of Supporting Electrolyte}

(Ammonium acetate buffer) $55.5 \mathrm{ml}$ of Suprapure acetic acid was taken in a $500 \mathrm{ml}$ volumetric flask. To this about $100 \mathrm{ml}$ of water was added. $37 \mathrm{ml}$ of Suprapure ammonia was added slowly to the volumetric flask. Ammonia had to be added slowly, because heat will be generated while addition. After the addition the solution was diluted to $500 \mathrm{ml}$ with ultra pure water. The ph of the buffer should be 4.6.

\section{Preparation of Standard Solution}

$1 \mathrm{mg} \mathrm{L}^{-1}$ standard of zinc was prepared for the Voltammetric analysis from stock solution of $1000 \mathrm{mg} \mathrm{L}$ 1 .

\section{Sample collection and Preparation/Digestion}

Milk samples were collected in $15 \mathrm{ml}$ graduated centrifuge tubes (Tarson: Cat. No.500030) from the various milk sample of different brands of Delhi, India. For the determination of Zinc, Milk sample digested and analyzed in same day.

\section{Anodic Stripping Voltammetric measurements}

$10 \mathrm{ml}$ ultra pure water and $1 \mathrm{ml}$ of acetate buffer $(\mathrm{pH} 4.6)$ was taken in polarographic vessel and then the measurement was started under the given parameters Table 1, after this voltamogramme of the blank was recorded. $1 \mathrm{ml}$ of digested milk sample was added to polarographic vessel and then voltamogramme of the sample solution was recorded under the same conditions. After the sample voltamogramme was recorded, $0.1 \mathrm{ml}$ of $1 \mathrm{mg} \mathrm{L} \mathrm{L}^{-1}$ Zinc standard was added twice and then voltamogramme of the standard was recorded (Fig. 1). ASV is the two step measurement .In the first step the zinc metal ions present in the test solution are get deposited on the mercury electrode surface (amalgamation) at deposition potential of $-1150 \mathrm{mV}$. In the second step all the deposited ions are anodically stripped by scanning the potential range from -1150 to + $100 \mathrm{mV}$.

Tab.1 Operating parameters for the determination of Zinc in milk sample by DPASV

\begin{tabular}{|c|c|}
\hline Parameters & Description \\
\hline Working electrode & $\begin{array}{l}\text { Hanging Mercury } \\
\text { Dropping Electrode }\end{array}$ \\
\hline Calibration & $\begin{array}{l}\text { Standard addition } \\
\text { method }\end{array}$ \\
\hline Number of replications & 3 \\
\hline Drop size & 4 \\
\hline Stirrer speed & $2000 \mathrm{rpm}$ \\
\hline Mode & Differential pulse \\
\hline Initial purge time & $300 \mathrm{~s}$ \\
\hline Addition purge time & $10 \mathrm{~s}$ \\
\hline Deposition potential & $-1.15 \mathrm{~V}$ \\
\hline Deposition time & $90 \mathrm{~s}$ \\
\hline Equilibration time & $10 \mathrm{~s}$ \\
\hline Pulse amplitude & $0.05 \mathrm{~V}$ \\
\hline Start potential & $-1.3 \mathrm{~V}$ \\
\hline End potential & $0.05 \mathrm{~V}$ \\
\hline Voltage step & $0.006 \mathrm{~V}$ \\
\hline Voltage step time & $0.1 \mathrm{~s}$ \\
\hline Sweep rate & $0.06 \mathrm{~V} / \mathrm{s}$ \\
\hline Peak potential (Zn) & $-9.80 \mathrm{~V}$ \\
\hline Peak potential $(\mathrm{Cd})$ & $-0.56 \mathrm{~V}$ \\
\hline Peak potential $(\mathrm{Pb})$ & $-0.38 \mathrm{~V}$ \\
\hline Peak potential $(\mathrm{Cu})$ & $-0.10 \mathrm{~V}$ \\
\hline
\end{tabular}

All the measurements are done by standard addition technique in which first the sample was taken into the polarographic vessel and the current was measured. After the addition of $100 \mu \mathrm{l}$ of standard soln. the procedure was repeated three times and the current was 


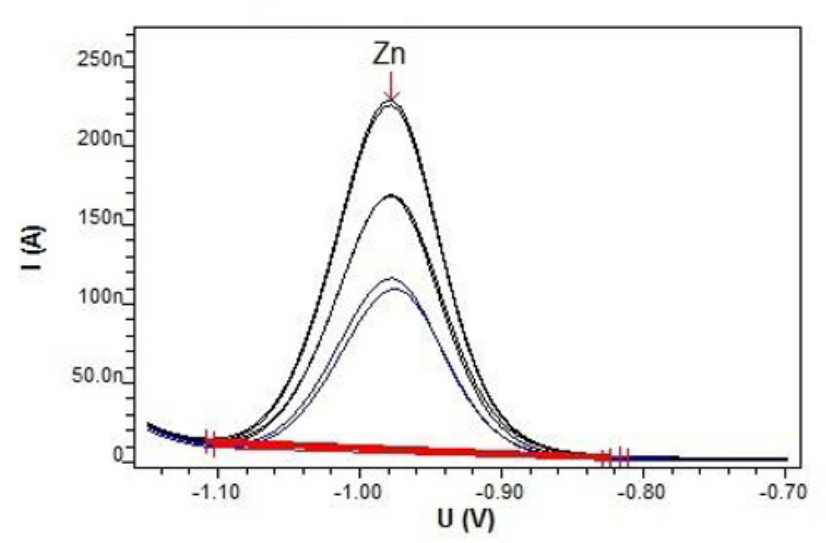

Fig.1 Voltommogramme obtanined for samples as well as for standards.Condition: scan rate, $59.5 \mathrm{mv} / \mathrm{s}$;Pulse amplitude, $50 \mathrm{mV}$;Deposition potential, $-1150 \mathrm{mV}$ vs $\mathrm{Ag} / \mathrm{AgCl}$; deposition time , 90s, equilibration time, 10 s; Sacnning range, -1150 to $100 \mathrm{mV}$

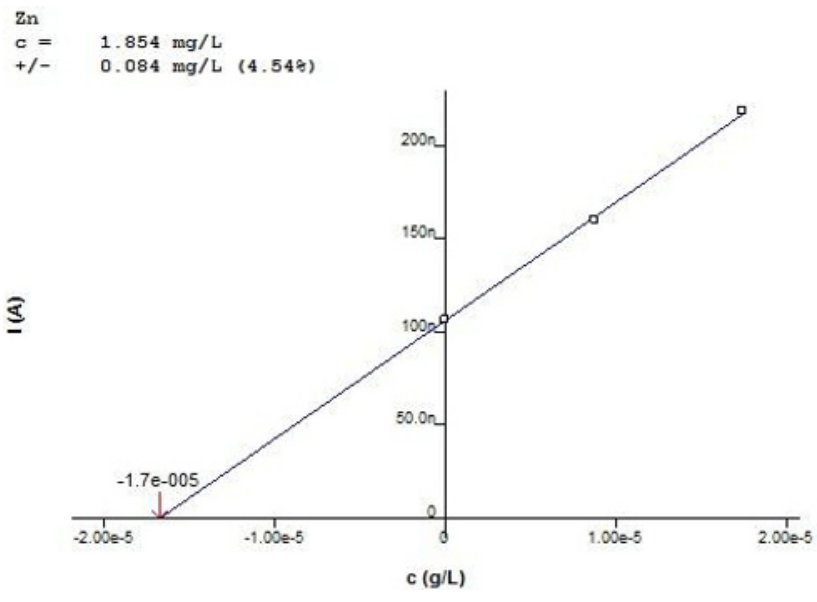

Fig.2 Extrapolation graph of $\mathrm{Zn}$

measured. After all the measurement extrapolation curve was plotted between current vs concentration. The extrapolation curve will show the amount of metals present in the sample solution. All the analysis was done with automatic blank subtraction feature of instrument. Voltamogramme of the standard and sample were shown in Fig. 1 and the exploration graph of $\mathrm{Zn}$ was shown in Fig. 2.

\section{Results and Discussion}

In this study, the concentration of the zinc metal in milk sample of different brands in Delhi, India was successfully determined by ASV technique .The mean concentration of $\mathrm{Zn}$ metal in milk sample of different brands of Delhi (India) was found to be $2.28 \mathrm{mgL}^{-1}$. Comparison of the elemental concentration of $\mathrm{Zn}$ in fresh milk in this study with published values is shown in Table No 2. Consequently, it is understood that the concentration of $\mathrm{Zn}$ in milk sample of different brands in Delhi (India) have no influence on the human health. Voltamogramme of the standard and sample were shown in figure 1 . The sensitivity was calibrated by standard additions to the sample and the metal concentrations initially were calculated by exploration the extraploration graph of Zn was shown in Fig. 2.

Many analytical methods has been published for the determination of Zinc but using one method in DPASAV for the analysis of four metal combined respectively $\mathrm{Zn}$ is presented in this work. The advantages of the proposed Voltammetric method over the other known techniques( AAS, ICPOES,etc) are that it is a successful, new, rapid, simple, selective and inexpensive technique for quantitative and qualitative determination of heavy metals and it has extremely low detection limits and can also works in the presence of high salt concentrations.

\section{Conclusion}

In this work, the most appropriate conditions were fixed to determine the amount of $\mathrm{Zn}$ through DAPSAV using single method on Hanging mercury drop electrode (HMDE). Direct determination of $\mathrm{Zn}$ in the milk sample of different brands.

Delhi (India) is possible by DAPSAV. Under working conditions the amount of $\mathrm{Zn}$ in milk sample has been successfully determined. It can be very useful for human health concern. This method is rapid, sensitive and less costly as compared to other analytical methods.

\section{References}

Abdallah M.I.M . Evaluation of some heavy metals residue in whole milk powder used at confectionary plant regarding the public health significance, Animal research institute, agricultural research center, Giza Egypt.(2011)

Ahmed, W.M.S, studies on heavy metal pollution forms in relation to production performance Ph.D thesis Fac. Of vet. Med zag university.(2002)

Bozene Hasnedlova, Jan Travnick, Vladislav Chrastny "Zinc and Copper Concentration in milk of dairy cows in the South Bhohemia Region, ISAH Warsaw, Poland vol 1( 2005)

Bulinski R, Bloniarz J, and Libelt B. Trace element content in in milk and some milk products. Bromat. chem.toskykol, (1992),327-331

Cortes, E., Das, H , A.,Tarafdar D A. and Vasconcellos, B A . Toxic Heavy metals and other trace element in food stuff from 12 different countries. Biological trace Element Research,20; (1994) 415-422

Farid S.M, Enani M.A and wajid S.A, Determination of trace elements in cow milk in Saudi Arabia, JKAU: Eg. Sci. volume 15(0-2) (2004) 131-140.

Korenekong B.M., Skalicka, and P. nai,Concentration of some heavy metals in cattle reared in the vicinity of metallurgic industry vet. Archiv. 72, (2002)254-267

Li-Quang, Xino- PingWang, WeLi, Xing Tong and WeiJun Tong. The minerals and heavy metals in cow`s milk from China and Japan. Journal of Health Science 555(2); (2009) 300-305.

Ogabiela E.E Yebpella G.G, Ade-Ajayi A.F, Mmereole U.J, Ezeayanaso C, Okonkwo E.m, Ahola D.O, Udiba U.U, Mahmood A. Determination of the level 
Tab.2 Comparison of the elemental concentration of $\mathrm{Zn}$ in fresh milk of different brands in this study with published values

\begin{tabular}{|c|c|c|c|c|c|c|c|c|c|c|c|c|}
\hline \multirow[t]{2}{*}{$\begin{array}{l}\text { Heavy } \\
\text { Metal }\end{array}$} & \multirow{2}{*}{$\begin{array}{l}\text { In } \\
\text { This } \\
\text { study } \\
\text { Value } \\
\text { of } \mathrm{Zn} \\
\text { (mg L- } \\
{ }^{1} \text { ) }\end{array}$} & \multicolumn{2}{|c|}{$\begin{array}{l}\text { Bis Indian } \\
\text { Standards } \\
\text { (IS 105000: } \\
1991) \\
\left(\mathrm{mg} \mathrm{L}^{-1}\right) \\
\end{array}$} & \multirow[t]{2}{*}{$\begin{array}{l}\text { WHO } \\
\left(\mathrm{mg} \mathrm{L}^{-1}\right) \\
\text { Maximum } \\
\text { allowable } \\
\text { concentrati } \\
\text { on }\end{array}$} & \multirow[t]{2}{*}{$\begin{array}{l}\text { EPA } \\
\\
(\mathrm{mg} \\
\left.\mathrm{L}^{-1}\right)\end{array}$} & \multirow[t]{2}{*}{$\begin{array}{l}\text { Semaghi } \\
\text { ul et al } \\
\text { (2008) } \\
\left(\mathrm{mg} \mathrm{L}^{-1}\right)\end{array}$} & \multirow[t]{2}{*}{$\begin{array}{l}\text { Abdallah } \\
(2011) \\
(\mathrm{mg} / \mathrm{Kg})\end{array}$} & \multirow{2}{*}{$\begin{array}{l}\text { Farid et } \\
\text { al } \\
(2004) \\
(\mu g \\
/ \mathrm{Kg})\end{array}$} & \multirow[t]{2}{*}{$\begin{array}{l}\text { Ostapezu } \\
\text { l et al } \\
(1987) \\
(\mu \mathrm{g} / \mathrm{Kg})\end{array}$} & \multirow{2}{*}{$\begin{array}{l}\text { Bulins } \\
\text { ki et al } \\
(1992) \\
(\mu \mathrm{g} \\
/ \mathrm{Kg})\end{array}$} & \multirow{2}{*}{$\begin{array}{l}\text { Cort } \\
\text { es et } \\
\text { al } \\
(199 \\
4) \\
(\mu \mathrm{g} \\
/ \mathrm{Kg})\end{array}$} & \multirow[t]{2}{*}{$\begin{array}{l}\text { Ogabiela } \\
\text { et al } \\
(2011) \\
\left(\mathrm{mg} \mathrm{L}^{-1}\right)\end{array}$} \\
\hline & & $\begin{array}{l}\text { Desir } \\
\text { able } \\
\text { limit }\end{array}$ & $\begin{array}{l}\text { Permissi } \\
\text { ble limit }\end{array}$ & & & & & & & & & \\
\hline $\mathrm{Zn}$ & 2.28 & 5.0 & 15 & 5.0 & 5.00 & 0.98 & $\begin{array}{l}3.661 \pm \\
0.003\end{array}$ & $\begin{array}{l}944.9 \pm \\
2.4\end{array}$ & 3730.0 & 3770.0 & $\begin{array}{l}3000 \\
.0\end{array}$ & $\begin{array}{l}3.239- \\
5.521\end{array}$ \\
\hline
\end{tabular}

of some elements in edible oils sold iz Zoria, northen Nigeria. Global Journal of pure and applied sciences vol. 6(3): (2010) 325-331.

Ostapezuk P, Valenta P,Rutzel H, and Nurnberg H. W, 1987. Determination of Heavy metal in environmental sample, sc. of total environ, (1987) 60:1-16

Semaghuil Binghila, Simona D, G. Stanciu, A. Soceanu, . Determination of Major and Minor
Elements in milk through ICP-AESEnviromental Engineering and Management Journal. No 6, (2008)805-808.

Yahaya M.I Ezaor G.C, Musa Y.F Muhamad S.Y. Analysis of heavy metals concentration in road side soils in Vauri, Nigeria. African journ. Of pure and applied chem. vol. 4 (3) (2010). 